\title{
Yield potential and fruit traits of the French- type 'Dwarf Superplátano' clone evaluated at three locations ${ }^{1,2}$
}

\author{
Héber Irizarry ${ }^{3}$, Ricardo Goenaga ${ }^{4}$ and Abraham D. Krikorian ${ }^{5}$
}

\author{
J. Agric. Univ. P.R. 82(3-4):173-181 (1998)
}

\begin{abstract}
The French-type 'Dwart Superplátano' (Musa AAE), a reverted clone selected from the local false horn-type 'Common Dwarf' plantain, was subjected to varlous bunch management treatments at three locations. The immature bunches were pruned to either three, four or flve uppermost hands. Those pruned to four and five hands were either sprayed with a gibberellic acid solution or not sprayed. Both sprayed and unsprayed bunches were immediately bagged or left unbagged. Spraying with gibberellic acid and bagging, alone or comblned, had no significant effect on bunch yield components nor on fruit traits. Regardless of location, pruning slgnificantly reduced bunch size and the time needed for truit filling. Bunches pruned to flve, four and three hands averaged 79, 66 and 50 fruits, respectively. PrunIng from five to three hands significantly reduced frult filling to 112 days. Pruning also affected bunch yleld and bunch mean frult welght, but the effect varled with locatlon. A reduction in bunch size from five to four hands at Corozal and from four to three hands at Salinas and Yauco substantially reduced bunch yield by 12 and $23 \%$, respectively. Bunch mean frult woight significantly Increased at the expense of reducing bunch size to three hands at Corozal and to four hands at Sallnas and Yauco. Bunch mean fruit weight at Corozal was always superlor to that at Yauco. Regardless of location, pruning significantly brought about an increase in frult size in the distal hand. The thickest and largest fruits were produced in bunches pruned to three hands, Likewise, pruning significantly increased mean fruit weight in the distal hand, but the effect varled with location. At Corozal, fruits in the distal hand of bunches pruned to three hands attalned the heaviest mean weight, $355 \mathrm{~g}$. Regardless of locatlon, a reduction in hands from five to four upgraded trulte in the distal hand from non-marketable to marketable by in-
\end{abstract}

1Manuseript submitted to Editorial Board 17 September 1997.

This paper covers work carried out cooperatively between the Agricultural Research Service-USDA and the Agricultural Experiment Station, University of Puerto Rico (AESUPR), Río Piedras, Puerto Rico. The authors are grateful to Nicolás Díaz, Javier Fuentes and Roberto Luciano, Agricultural Research Technicians, for their assistence in carrying out the experiments, and to Mary E. Scott for micropropagating the 'Dwarf Superplátano'.

'Research Horticulturist, Tropical Agriculture Research Station, P. O. Box 70, Mayagitez, P.R. 00681.

Research Plant Physiologiat, Tropical Agriculture Research Station, P. O. Box 70, Mayagdez, P.R. 00681.

"Professor, Department of Biochemistry and Cell Biology, State University of New York at Stony Brook, N.Y. 11794-5215. 
creasing their weight to over $\mathbf{2 7 0} \mathrm{g}$. We inferred that under intensive management the French-type 'Dwarf. Superplátano' clone with the bunch pruned to four uppermost hands has the potentlal to yield 173,000 fruits per hectare, equivalent to $\mathbf{5 7 . 6} \mathrm{t}$ of fruits per hectare. These fruits conform to the local marketing standards establlshed for the 'Marlcongo' plantain.

Key words: French-type 'Dwart plantain', Musa AAB, bunch pruning, fruit quality, yleld

\section{RESUMEN}

Rendimiento y caracteristicas de las frutas del 'Superplátano' francésenano evaluado en tres localidades

El 'Superplátano' tipo francés-enano (Musa AAB), una selección clonal del plátano local 'Enano-Común' tipo cuerno, se sometió a varios tratamientos de manejo del racimo en tres localidades. Dos semanas después de emerger los racimos tiernos, estos se podaron hasta dejar las tres, cuatro o cinco manos superlores del racimo. Algunos de los racimos podados a cuatro y cinco manos se asperjaron con una solución de ácido giberélico mlentras que otros se dejaron sin asperjar. Algunos de los racimos asperjados y sin asperjar se entundaron con bolsas de polietileno y otros se dejaron sin enfundar. Los tratamientos con el regulador de crecimlento y el enfundado, solos o combinados, no tuvieron efectos signifleativos sobre los componentes de rendimiento y las caracteristicas de las frutas. Irrespectivo de la localidad, la poda redujo significativamente el tamafio del racimo y los días necesarios para el engorde de las frutas. Los racimos podados a cinco, cuatro y tres manos promediaron 79,66 y 50 frutas, respectivamente. La poda a tres manos redujo el tlempo de engorde de las frutas a 112 días. La poda también afectó el peso del racimo y el peso medio de las frutas en el racimo pero el efecto varió por localldad. La reducción on el tamaño del racimo de cinco a cuatro manos en Corozal y de cuatro a tres manos on Salinas y Yauco redujo sustancialmente el rendimiento en 12 y 23\%, respectivamente. El peso medlo de todas las frutas en el racimo aumentó significativamente a expensas de la reducción en el tamaño del racimo a tres manos en Corozal y a cuatro manos en Salinas y Yauco. El peso medlo de las frutas en Corozal fue slempre superior al obtenido en Yauco. Irrespectivo de la localldad, la poda incrementó significativamente el tamaño de las frutas en la última mano del racimo. Las frutas de mayor grosor y largo se produjeron en los racimos podados a tres manos. Igualmente, la poda aumentó sustancialmente el peso medio de las frutas en la última mano pero el efecto dependíó de la localidad. En Corozal las frutas en la última mano de los racimos podados a tres manos alcanzaron el mayor peso promedlando $355 \mathrm{~g}$. Irrespectivo de la localidad, la reducción en el tamaño del racimo de cinco a cuatro manos promovló la clasificación de las frutas en la última mano de no mercadeables a mercadeables al adquirir un peso mayor a los $270 \mathrm{~g}$. Inferimos que bajo manejo intensivo el clon Superplátano trancés-enano con el racimo podado a cuatro manos superiores tlene el potencial de producir $\mathbf{1 7 3 , 0 0 0}$ frutas mercadeables por hectérea, equivalente a $\mathbf{5 7 . 6} \mathrm{t}$ de frutas por hectárea. Estas frutas cumplen con los requileltos locales de mercadeo establecidos para ol plátano 'Maricongo'.

\section{INTRODUCTION}

The cost of plantain production in Puerto Rico has increased about 27\% since 1986 (Irizarry and Montalvo-Zapata, 1986; Anonymous, 1995). During the same period the farm-gate value of the crop has in- 
creased by only $16.7 \%$ (Soto-Santiago et al., 1996). For plantain to remain a profitable crop without affecting the consumer price, it will be necessary to increase yield to compensate for the increased cost of production.

Currently, about $90 \%$ of the local plantain production originates from the false-horn 'Maricongo' clone, and the local market grading system is based on its fruit traits. A Maricongo' fruit is considered marketable if it weighs $270 \mathrm{~g}$ or more, and attains a superior grading when the outer length of the intact fruit reaches $25.4 \mathrm{~cm}$ or more (SotoSantiago, 1994). The yield potential of 'Maricongo' is about 45 marketable fruits per bunch; however, the clone is unstable for bunch genotype and number of hands and fruits (Irizarry et al., 1985; Krikorian et al., 1993). Under conventional propagation, bunch reversion from falsehorn to French-type is relatively low (Irizarry et al., 1985), but depending on pre-existing factors such as the presence of chimerism in the primary explant, the problem is exacerbated when in vitro micropropagation is used (Krikorian et al., 1993).

The use of French-type plantain clones for commercial production is increasing in popularity. Current genetic improvement programs focus on the development of disease resistant French-type tetraploid hybrids for the export market (Vuylsteke et al., 1993; Rowe, 1994). The 'Superplatano', a stable French-type triploid clone selected from the reverted false-horn 'Maricongo', has the capacity to yield over $20 \%$ more than its counterpart if proper bunch management is used (Irizarry and Goenaga, 1995; 1997). Both clones, however, develop a tall pseudostem (over $3.5 \mathrm{~m}$ ), which renders the plant susceptible to wind damage, and makes bunch management more difficult, particularly when grown on steep land.

In an attempt to overcome these problems, a French-type 'Dwarf Superplátano' clone (Musa AAB) was selected from the false-horn Common Dwarf plantain. This stable clone develops a shorter pseudostem, 2.4 to $2.6 \mathrm{~m}$ in height, and produces bunches containing 8 to 9 hands with 120 to 135 undersized and underweight fruits (Unpublished data). These fruits, however, are not marketable in Puerto Rico unless the size and weight is increased.

The technique of pruning lower hands of a bunch has been successfully used to improve fruit traits in French-type plantains (Irizarry et al., 1991). Bunch bagging (González and Soto, 1985) and gibberellic acid $\left(\mathrm{GA}_{\mathrm{g}}\right.$ ) applications (Tadros et al., 1984) have also been reported to increase yield and improve fruit quality in bananas, Musa AAA.

To upgrade fruits from non-marketable to marketable, and to determine the yielding capacity of the clone, we applied various bunch treatments to 'Dwarf Superplátano' at three locations. 


\section{MATERIALS AND METHODS}

Three experiments were established May, June and July 1994 in the municipalities of Yauco, Salinas and Corozal, respectively. The Yauco experiment was located on a private farm in the Barinas ward, about $35 \mathrm{~m}$ elevation. Mean historical annual rainfall is $990 \mathrm{~mm}$, and class A pan evaporation is $2,040 \mathrm{~mm}$ (Hadeen, 1990). The soil is a San Antón silty clay (Cumulic Haplustolls, fine loamy, mixed, isohyperthermic) (Lugo-López et al., 1995). Soil from the top 25-cm layer had $\mathrm{pH}$ of 7.4, contained $9.8 \mathrm{mg} / \mathrm{kg}$ of $\mathrm{P}$ (Olsen method) and had an exchangeable cation capacity of $31.9 \mathrm{cmol}(+) / \mathrm{kg}$ of soil. Throughout the duration of the experiment the plants were drip irrigated at the weekly rate of $55 \mathrm{~L} /$ plant, somewhat less than the 0.75 Class $A$ pan factor recommended for the region (Goenaga and Irizarry, 1995).

The Salinas experiment was carried out on a private farm in the Aguirre ward, about $20 \mathrm{~m}$ elevation. Mean historical annual rainfall and Class A pan evaporation are 1,070 and 2,150 mm, respectively (Hadeen, 1990). The soil is a Fraternidad clay (Typic Haplusterts, fine, montmorillonitic, isohyperthermic) (Lugo-Lopez et al., 1995). Soil from the top 25$\mathrm{cm}$ layer had a pH of 7.5 , contained $10.3 \mathrm{mg} / \mathrm{kg}$ of $\mathrm{P}$ (Olsen method) and had an exchangeable cation capacity of $28.3 \mathrm{cmol}(+) / \mathrm{kg}$ of soil. During the planting-to-harvest cycle the plants were drip-irrigated. Each plant received approximately $85 \mathrm{~L}$ of water weekly, equivalent to the region estimated Class A pan factor of 1.0 (Goenaga and Irizarry, 1995). Both Yauco and Salinas experiments were located in the semiarid region, where rainfall is low and evaporation high. However, an appreciable amount of rainfall occurs during the months of May and August through November. During these months the irrigation scheme was modified to consider the amount of rainfall recorded the previous week.

The Corozal experiment was located at the Corozal substation (AES-UPR) in the north-central upland region, about $200 \mathrm{~m}$ elevation. Throughout the experiment the mean monthly minimum and maximum temperatures were 19.8 and $31.1^{\circ} \mathrm{C}$, respectively. Annual rainfall was $1,590 \mathrm{~mm}$; Class A pan evaporation $1,400 \mathrm{~mm}$. In addition to the rainfall, the plants received supplemental drip irrigation at the weekly rate of $25 \mathrm{~L} /$ plant. The actual weekly irrigation applied depended on the amount of water lost through evapotranspiration after subtracting any recorded rainfall from the previous week (Goenaga and Irizarry, 1995). The soil is a Corozal clay (Aquic Haplohumults, clayey, mixed, isohyperthermic) (Lugo-Lopez et al., 1995). In the top 25-cm layer the $\mathrm{pH}$ was raised to about 5.2 with the application of limestone at the rate of 5.0 t/ha. The soil contained $6.2 \mathrm{mg} / \mathrm{kg}$ of $P$ (Bray method 2), and had an exchangeable cation capacity of $9.9 \mathrm{cmol}(+) / \mathrm{kg}$ of soil. 
The planting material was originated from in vitro micropropagated plants, that had reached about 25-cm height. Cultures had been initiated from shoot tips and male floral stem tips (Krikorian et al, 1993). The plants were spaced $1.22 \mathrm{~m}$ apart in the row with $3.05 \mathrm{~m}$ between rows, approximately 2,628 plants per hectare. Each row accommodated 18 experimental plants per replication. The experiment was surrounded by guard rows.

At planting, plants were fertilized with $11 \mathrm{~g}$ of $\mathrm{P}$ as triple superphosphate placed on the bottom of the furrow. Two weeks later, plants in Salinas and Yauco experiments began receiving weekly applications of $\mathrm{N}$ and $\mathrm{K}$ through the drip system at the rate of 7.8 and $16.1 \mathrm{~kg} / \mathrm{ha}$, respectively. A total of $280 \mathrm{~kg} / \mathrm{ha}$ of $\mathrm{N}$ and $581 \mathrm{~kg} / \mathrm{ha}$ of $\mathrm{K}$ were applied until the plants reached the bunch-emergence peak, about nine months after planting. The Corozal experiment was fertilized with $2,800 \mathrm{~kg} / \mathrm{ha}$ of a 10-0-25-3 (N, $\left.\mathrm{P}_{2} \mathrm{O}_{5}, \mathrm{~K}_{2} \mathrm{O}, \mathrm{MgO}\right)$ fertilizer. The granular mixture was applied at the rate of $600,800,800$ and $600 \mathrm{~kg} / \mathrm{ha}$, respectively, at 2,5 , 8 and 10 months after planting. In addition, plants at Corozal received two applications of kieserite $\left(\mathrm{Mg} \mathrm{SO}_{4} \cdot \mathrm{H}_{2} \mathrm{O}, 17.5 \% \mathrm{Mg}\right)$ at the rate of 147 $\mathrm{kg} / \mathrm{ha}$.

Two weeks after bunch-emergence, the immature bunches were subjected to nine treatments. Bunches were pruned to either three, four or five uppermost hands. Those pruned to four and five hands were either sprayed with a Pro-Gibb ${ }^{8}$ solution containing $50 \mathrm{ml} / \mathrm{L}$ of gibberellic acid or not sprayed. The solution was supplemented with $3 \mathrm{ml}$ of the sticker X-77 Spreader per 3.8 L of water. Both sprayed and unsprayed bunches were immediately bagged with clear polyethylene bags or left unbagged. Bunches pruned to three hands were neither sprayed nor bagged. Bunch pruning (main-treatment) and hormone spraying and bagging (subtreatment) were arranged in a split plot design with four replications. Each subtreatment contained ten observations per replication.

Yellow sigatoka, nematodes, corm-weevil and weeds were controlled by following the recommendations contained in the plantain and banana technological package of practices (Anonymous, 1995). Yellow sigatoka is not a problem on plantain grown in the semiarid region. Therefore, foliar spraying was not necessary at Salinas or Yauco.

The bunches were harvested when fruits reached the mature-green stage, 112 to 117 days after bunch emergence. At harvest, the bunches were weighed, fruits per hand counted, and bunch mean fruit weight .

'Mention of a trade name in this publication is only to provide specific information. It does not constitute a warranty of materials by the USDA-ARS or the AES-UPR, nor is this mention a statement of preference over other materials 
was determined. Four fruits from the two rows in the middle section of the distal hand of each bunch were sampled to determine fruit diameter, inner and outer lengths and mean weight. Fruit length was measured following the inner and outer curvature of the fruit from the pedicel to the butt. The data were statistically analyzed by using the ANOVA procedure and the means compared by using Tukey's HSD test at $P \leq 0.05$.

\section{RESULTS AND DISCUSSION}

Spraying with gibberellic acid and bagging subtreatments alone or combined had no significant effect on bunch and fruit traits of the 'Dwarf Superplátano' (data not shown).

Regardless of location, bunch pruning significantly affected bunch size and days needed for fruit filling (Table 1). The 'Dwarf Superplátano' bunch pruned to five, four and three uppermost hands contained 79,66 and 50 fruits, respectively. This production was similar to that attained by the tall Superplatano clone at Corozal but with the bunch pruned to six, five and four hands (Irizarry and Goenaga, 1997). A marked yield component difference between the two clones is the mean number of fruits in the uppermost hands. The 'Dwarf Superplatano' with the bunch pruned to five hands averaged 15.8 fruits per hand, whereas the tall 'Superplátano' pruned to five hands averaged only 12.2 fruits per hand. A reduction in hands from five to three also hastened bunch harvest by reducing the time needed for fruit filling from 117 to 112 days (Table 1).

Pruning significantly affected bunch weight and bunch mean fruit weight, but the effect depended on location (Tables 2 and 3). A reduction in hands from five to four at Corozal and to fewer than four at Salinas and Yauco caused a substantial reduction in bunch weight. Bunches pruned to three and five hands at Corozal and to five hands at Salinas were significantly heavier than those pruned to a similar num-

TABLE 1.-Effect of bunch pruning on size of bunch and time needed for fruit filling in the 'Dwarf Superplatano' clone.

\begin{tabular}{lcc}
\hline Pruning treatment & Fruits per bunch & Days needed for fruit flling \\
\hline & no. & no. \\
Five hands & $79.2 \mathrm{a}^{1}$ & $117.0 \mathrm{a}$ \\
Four hands & $66.1 \mathrm{~b}$ & $115.2 \mathrm{ab}$ \\
Three hands & $60.4 \mathrm{c}$ & $111.7 \mathrm{~b}$ \\
\hline
\end{tabular}

'Means within a column followed by the same letter do not differ significantly at the 0.05 probability level. 
J: Agric. Univ. P.R: VOL. 82, NO. 3-4, JULY=OCTOBER 1998* 179

TABLE 2,-Effect of bunch pruning on bunch weight of the Dwarf Superplatano' clone planted at three locations.

Location

\begin{tabular}{lccc} 
& Corozal & Salinas & Yauco \\
\cline { 2 - 4 } Pruning treatment & Bunch weight & Bunch weight & Bunch weight \\
\hline & $\mathrm{kg}$ & $\mathrm{kg}$ & $\mathrm{kg}$ \\
Five hands & $24.2 \mathrm{a}^{\mathrm{L}, 2}$ & $24.2 \mathrm{a}$ & $22.2 \mathrm{a}$ \\
Four hands & $21.4 \mathrm{~b}$ & $22.5 \mathrm{a}$ & $21.7 \mathrm{a}$ \\
Three hands & $18.8 \mathrm{~b}$ & $17.2 \mathrm{~b}$ & $16.6 \mathrm{~b}$
\end{tabular}

'Means within a column followed by the same letter do not differ significantly at the 0.05 probability level.

${ }^{2}$ Means within a row do not differ significantly at the 0.05 probability level unless the difference exceeds 1.7.

ber of hands at Yauco. This reduction in bunch weight may be due to the reduced amount of irrigation applied by the farmer at the Yauco experiment. Plants at this site did not receive the equivalent of a Class $A$ pan factor of 0.75 recommended for the region (Goenaga and Irizarry, 1995).

Bunch mean fruit weight significantly increased at the expense of a reduction in bunch size from five to three hands at Corozal and to four hands at Salinas and Yauco (Table 3). Regardless of pruning treatments, bunch mean fruit weight at Corozal was always significantly superior to that at Yauco. The Corozal bunches pruned to three hands yielded the heaviest fruits, with a bunch mean fruit weight of $376 \mathrm{~g}$.

TABLE 3.-Effect of bunch pruning on bunch fruit mean weight of the Dwarf Superplatano' clone planted at three locations.

\begin{tabular}{|c|c|c|c|}
\hline \multirow[b]{3}{*}{ Pruning treatment } & \multicolumn{3}{|c|}{ Location } \\
\hline & Corozal & Salinas & Yauco \\
\hline & Fruit mean weight & Fruit mean weight & Fruit mean weight \\
\hline & $\mathbf{g}$ & $\mathbf{g}$ & $\mathbf{g}$ \\
\hline Three hands & $376.7 \mathrm{a}^{1,8}$ & $342.0 \mathrm{a}$ & $325.0 \mathrm{a}$ \\
\hline Four hands & $389.9 \mathrm{ab}$ & $337.5 \mathrm{a}$ & $315.7 \mathrm{a}$ \\
\hline Five hands & $810.7 \mathrm{~b}$ & $299.8 \mathrm{~b}$ & $281.5 \mathrm{~b}$ \\
\hline
\end{tabular}

Means within a column followed by the same letter do not differ significantly at the 0.05 probability level.

Means within a row do not differ significantly at the 0.05 probability level unless the difference exceeds 20.9 . 
TABLE 4.-Effect of bunch pruning on the size of fruits in the distal hand of the Dwarf Superplatano' bunch.

\begin{tabular}{lccc}
\hline Pruning treatment & Fruit diameter & Fruit inner length & Fruit outer length \\
\hline & $\mathrm{mm}$ & $\mathrm{cm}$ & $\mathrm{cm}$ \\
Three hands & $43.9 \mathrm{a}^{1}$ & $21.9 \mathrm{a}$ & $28.0 \mathrm{a}$ \\
Four hands & $43.6 \mathrm{a}$ & $20.6 \mathrm{~b}$ & $26.2 \mathrm{~b}$ \\
Five hands & $41.9 \mathrm{~b}$ & $18.5 \mathrm{c}$ & $24.2 \mathrm{c}$ \\
\hline
\end{tabular}

'Means within a column followed by the same letter do not differ significantly at the 0.05 probability level.

Regardless of location, pruning significantly affected fruit size in the distal hand of the 'Dwarf Superplátano' bunch (Table 4). A reduction in hands from five to either four or three caused a significant increment in fruit diameter, and inner and outer lengths. On the basis of the outer length, these fruits surpassed the superior grading criteria established. for the 'Maricongo' plantain (Soto-Santiago, 1994). Likewise, mean fruit weight in the distal hand significantly increased at the expense of reducing bunch size but the effect varied with the location (Table 5). A reduction in hands from five to four upgraded fruits in the distal hand from non-marketable to marketable, over $270 \mathrm{~g}$ at all locations. At Corozal, however, the bunch pruned to three hands yielded the heaviest fruits, with a mean weight of $355 \mathrm{~g}$. These fruits were of a grade superior to those harvested from similarly pruned bunches at Salinas and Yauco.

We infer that under intensive management, regardless of location, the 'Dwarf Superplátano' clone with the bunch pruned to the four up-

TABLE 5.-Effect of bunch pruning on the mean weight of fruits in the distal hand of the 'Dwarf Superplatano' clone planted at three locations.

\begin{tabular}{|c|c|c|c|}
\hline \multirow[b]{3}{*}{ Pruning Treatment } & \multicolumn{3}{|c|}{ Location } \\
\hline & Corozal & Salinas & Yauco \\
\hline & Fruit mean weight & Fruit mean weight & Fruit mean weight \\
\hline Three hands & $\begin{array}{c}\mathrm{g} \\
355.1 \mathrm{a}^{1,8}\end{array}$ & $\begin{array}{c}g \\
304.9 \mathrm{a}\end{array}$ & $\begin{array}{c}\mathrm{g} \\
281.8 \mathrm{a}\end{array}$ \\
\hline Four hands & $291.9 \mathrm{~b}$ & $288.6 \mathrm{ab}$ & $285.7 \mathrm{a}$ \\
\hline Five hands & $237.5 \mathrm{c}$ & $256.9 \mathrm{~b}$ & $218.8 \mathrm{~b}$ \\
\hline
\end{tabular}

'Means within a column followed by the same letter do not differ significantly at the 0.05 probability level.

2Means within a row do not differ significantly at the 0.05 probability level unless the difference exceeds 17.9. 
permost hands has the potential to yield 173,000 fruits/ha, about $57.6 \mathrm{t}$ of fruits/ha. These yields compared to those reported for the tall 'Superplátano', but with the bunch pruned to five hands at Corozal (Irizarry and Goenaga, 1997). Except for inner length, other fruit traits in the distal hand of the 'Dwarf Superplátano' bunch pruned to four hands surpassed those of the tall 'Superplatano' bunch pruned to five hands.

\section{LITERATURE CITED}

Anonymous, 1995. Conjunto tecnológico para la producción de plátanos y guineos. Publ. 97, Esta. Exp. Agric. Univ. P.R.

Goenaga, R. and H. Irizarry, 1995. Yield performance of banana irrigated with fractions of Class A pan evaporation in a semiarid environment. Agron. J. 57:172-176.

Gonzalez, M. and M. Soto, 1985. Effect of bagging on the fruit quality of the banana (Musa AAA), Cavendish 'Great Dwarf'. Proc. ACORBAT, 7th Meet. (Sept. 23-27), San José, Costa Rica 347-350.

Hadeen, K. D., 1990. Climatological data annual summary-Puerto Rico and Virgin Islands. NOAA 36(13), Dept. of Commerce, National Climatic Data Center, Asheville, N.C.

Irizarry, H. and R. Goenaga, 1995. Yield and quality of 'Superplátano' (Musa AAB) grown with drip irrigation in the semiarid region of Puerto Rico. J. Agric. Univ. P.R. 79(12):1-11.

Irizarry, H. and R. Goenaga, 1997. Yield and fruit quality of the 'Superplátano' grown on an Ultisol with supplemental irrigation. J. Agric. Univ. P.R. 81(3-4):141-149.

Irizarry, H., J. A. Rodríguez-Garcia and N. Díaz, 1985. Selection and evaluation of high yielding horn-type plantain clones in Puerto Rico: An explanation for their behaviour. J. Agric, Univ. P.R. 69(8):407-420.

Irizarry, H. and R. Montalvo-Zapata, 1986. Conjunto tecnológico para la producción de plátanos y guineos. Publ. 97, Esta. Exp. Agric. Univ. P.R.

Irizarry, H., E. Rivera, A. D. Krikorian and J. A. Rodriguez, 1991. Proper bunch management of the French-type superplantain (Musa acuminata $\times$ M. balbisiana, AAB) in Puerto Rico. J. Agric. Univ. P.R. 75(2):163-171.

Krikorian, A. D., H. Irizarry, S. S. Cronauer-Mitra and E. Rivera, 1993. Clonal fidelity and variation in plantain (Musa $\mathrm{AAB}$ ) regenerated from vegetative stem and floral axis tips in vitro. Annals of Botany 71:519-535.

Lugo-López, M. A., F. H. Beinroth, R. L. Vick, G. Acevedo and M. A. Vázquez, 1995. Updated taxonomic classification of the soils of Puerto Rico, 1994. Bull. 294, Agric. Exp. Sta. Univ. P.R.

Rowe, P., 1994. Banana and plantain improvement program (Major accomplishments 1984 -94). FHIA, San Pedro Sula, Honduras.

Soto-Santiago, N., 1994. Especificaciones de calidad para la compra de plátanos bajo la unidad de compraventa de productos agrícoles del programa de mercadeo. Depto. de Agricultura, Administración de Servicios Agrícolas, Santurce, P.R.

Soto-Santiago, N., F. Meléndez-Luna and A. M. Cruz-Medina, 1996. Facts and figures on agriculture in Puerto Rico. Dept. of Agriculture, Office of Agricultural Statistics, San Juan, P.R.

Tadros, M. R., A. S. Khalifa, A. Z. Bondok and M. B. Bastauros, 1984. Effect of GAa application on the growth of banana bunches. Annals Agric. Sci., Fac. Agric. Ain Shams Univ., Cairo, Egypt 29(1):485-492.

Vuylsteke, D., R. S. Swennen and R. Ortiz, 1993. Registration of 14 improved tropical Musa plantain hybrids with black sigatoka resistance. HortScience 28(9):957-959. 